\title{
Teaching NeuroImages: Neuromyopathy in a patient with hereditary transthyretin Thr60Ala amyloidosis
}

Marcus V. Pinto, MD, Jennifer A. Tracy, MD, Martha Grogan, MD, and Michelle L. Mauermann, MD Neurology ${ }^{\circledR}$ 2019;92:e1403-e1404. doi:10.1212/WNL.0000000000007143

\section{Correspondence}

Dr. Mauermann

mauermann.michelle@

mayo.edu.

Figure Amyloid deposits in skeletal muscle and skin in a patient with hATTR amyloidosis
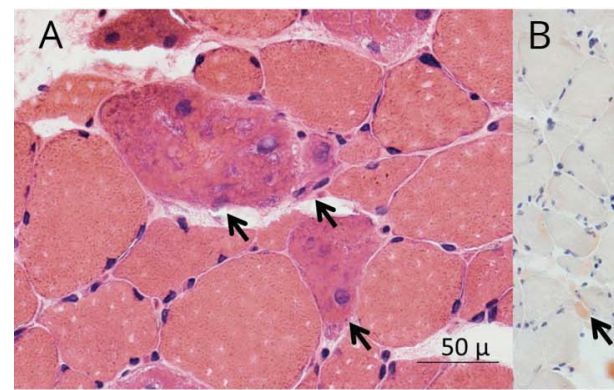

D

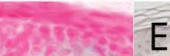

E
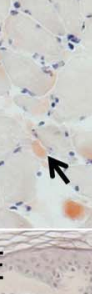

r

T

T.

$\pi$

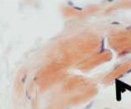

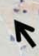

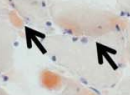

T

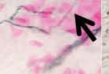

\section{r}
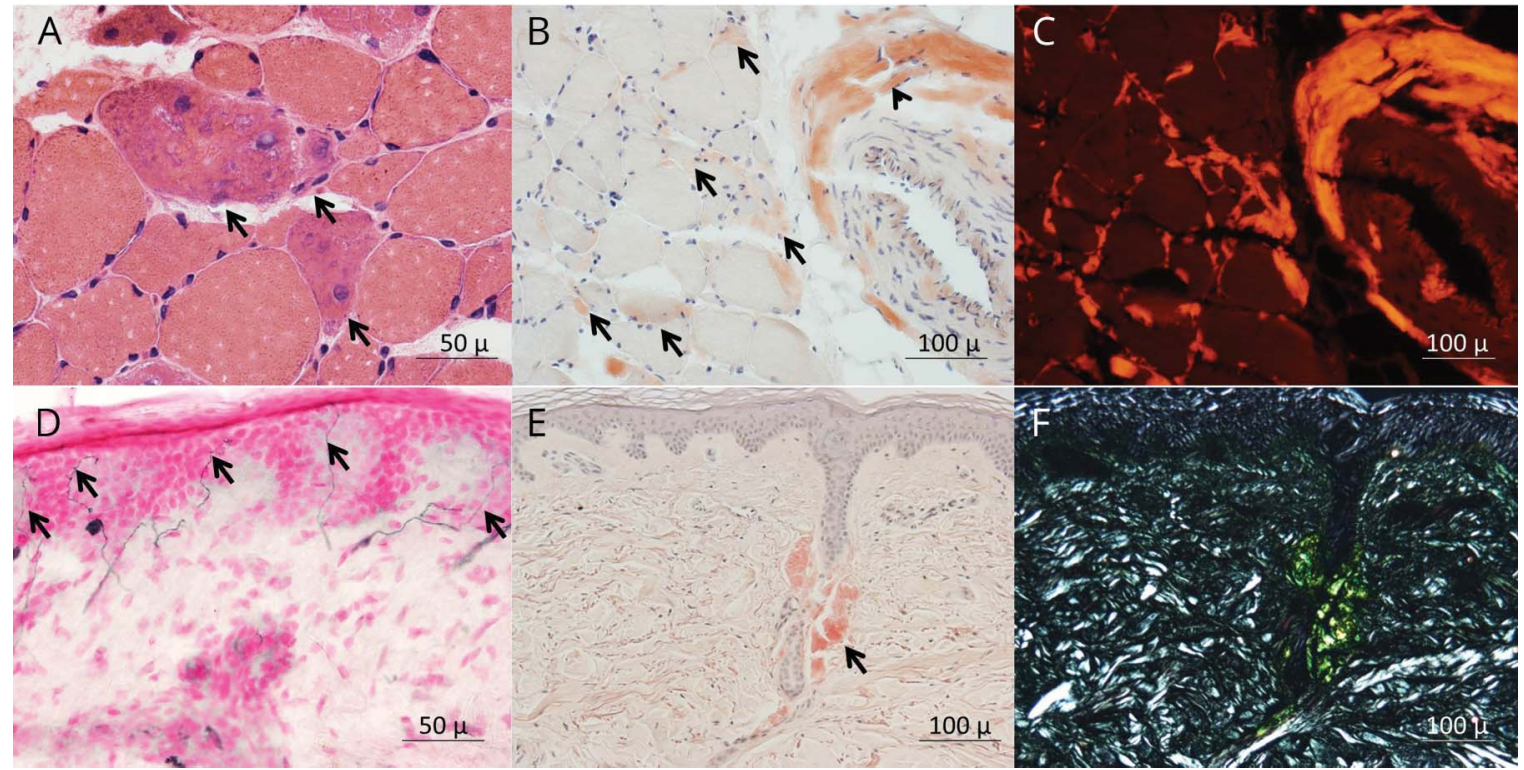

(A-C) Frozen sections of right gluteus medius muscle show $(A)$ regenerating muscle fibers on hematoxylin \& eosin stained-section and (B) extensive congophilic amorphous deposits adjacent to a large perimysial vessel (arrowhead) and in the endomysium surrounding many muscle fibers (arrows) on a Congo red-stained section (C) with red fluorescence viewed under rhodamine optics. (D-F) Skin punch biopsy of the right dorsal foot shows (D) numerous epidermal nerve fibers (arrows) with a mean intraepidermal nerve fiber density of 2.0 fibers $/ \mathrm{mm}$ ( $\mathrm{n}>0.2 \mathrm{fibers} / \mathrm{mm}$ ) on PGP 9.5 and (E) large congophilic amorphous deposits around a dermal vessel on Congo red preparation (F) with apple-green birefringence viewed under polarized light.

A 69-year-old man with hereditary transthyretin (hATTR) Thr60Ala amyloid cardiomyopathy presented with a 2-year history of proximal greater than distal weakness and pan-modality sensation loss in the lower extremities. Nerve conduction studies/EMG revealed a proximal myopathy and length-dependent axonal polyneuropathy. Muscle biopsy was diagnostic of amyloid myopathy (figure) and skin biopsy showed large amyloid deposits but normal intraepidermal nerve fiber density (figure). Myopathy is rare in hATTR amyloidosis and concomitant polyneuropathy is always present. ${ }^{1}$ Skin biopsy is less invasive than nerve biopsy and has good sensitivity for amyloid diagnosis. ${ }^{2}$ hATTR amyloidosis is treatable and should be included in the differential diagnosis of a neuromyopathy.

\section{MORE ONLINE}

$\rightarrow$ Teaching slides

links.lww.com/WNL/

A837

\section{Study funding}

No targeted funding reported.

From the Departments of Neurology (M.V.P., J.A.T., M.L.M.) and Cardiovascular Disease (M.G.), Mayo Clinic, Rochester, MN. 


\section{Disclosure}

M. Pinto, J. Tracy, M. Grogan, and M. Mauermann report no disclosures relevant to the manuscript. Go to Neurology.org/N for full disclosures.

Appendix Authors

\begin{tabular}{|c|c|c|c|}
\hline Name & Location & Role & Contribution \\
\hline $\begin{array}{l}\text { Marcus V. } \\
\text { Pinto, MD }\end{array}$ & $\begin{array}{l}\text { Mayo } \\
\text { Clinic, } \\
\text { Rochester, } \\
\text { MN }\end{array}$ & Author & $\begin{array}{l}\text { Data collection, drafting of final } \\
\text { manuscript, approval and } \\
\text { critical review of final form }\end{array}$ \\
\hline $\begin{array}{l}\text { Jennifer A. } \\
\text { Tracy, MD }\end{array}$ & $\begin{array}{l}\text { Mayo } \\
\text { Clinic, } \\
\text { Rochester, } \\
\text { MN }\end{array}$ & Author & $\begin{array}{l}\text { Data collection, approval and } \\
\text { critical review of final form }\end{array}$ \\
\hline $\begin{array}{l}\text { Martha } \\
\text { Grogan, MD }\end{array}$ & $\begin{array}{l}\text { Mayo } \\
\text { Clinic, } \\
\text { Rochester, } \\
\text { MN }\end{array}$ & Author & $\begin{array}{l}\text { Data collection, approval and } \\
\text { critical review of final form }\end{array}$ \\
\hline $\begin{array}{l}\text { Michelle L. } \\
\text { Mauermann, } \\
\text { MD }\end{array}$ & $\begin{array}{l}\text { Mayo } \\
\text { Clinic, } \\
\text { Rochester, } \\
\text { MN }\end{array}$ & Author & $\begin{array}{l}\text { Data collection, drafting of final } \\
\text { manuscript, approval and } \\
\text { critical review of final form }\end{array}$ \\
\hline
\end{tabular}

\section{References}

1. Yamashita T, Ando Y, Katsuragi S, et al. Muscular amyloid angiopathy with amyloidgenic transthyretin Ser50Ile and Tyr114Cys. Muscle Nerve 2005;31: $41-45$.

2. Ebenezer GJ, Liu Y, Judge DP, et al. Cutaneous nerve biomarkers in transthyretin familial amyloid polyneuropathy. Ann Neurol 2017;82:44-56. 


\section{Neurology}

\section{Teaching NeuroImages: Neuromyopathy in a patient with hereditary transthyretin Thr60Ala amyloidosis}

Marcus V. Pinto, Jennifer A. Tracy, Martha Grogan, et al. Neurology 2019;92;e1403-e1404

DOI 10.1212/WNL.0000000000007143

\section{This information is current as of March 18, 2019}

\section{Updated Information \&} Services

References

Subspecialty Collections

Permissions \& Licensing

Reprints including high resolution figures, can be found at: http://n.neurology.org/content/92/12/e1403.full

This article cites 2 articles, 0 of which you can access for free at: http://n.neurology.org/content/92/12/e1403.full\#ref-list-1

This article, along with others on similar topics, appears in the following collection(s):

Muscle disease

http://n.neurology.org/cgi/collection/muscle_disease

Peripheral neuropathy

http://n.neurology.org/cgi/collection/peripheral_neuropathy

Information about reproducing this article in parts (figures,tables) or in its entirety can be found online at:

http://www.neurology.org/about/about_the_journal\#permissions

Information about ordering reprints can be found online:

http://n.neurology.org/subscribers/advertise

Neurology ${ }^{\circledR}$ is the official journal of the American Academy of Neurology. Published continuously since 1951, it is now a weekly with 48 issues per year. Copyright (O 2019 American Academy of Neurology. All rights reserved. Print ISSN: 0028-3878. Online ISSN: 1526-632X.

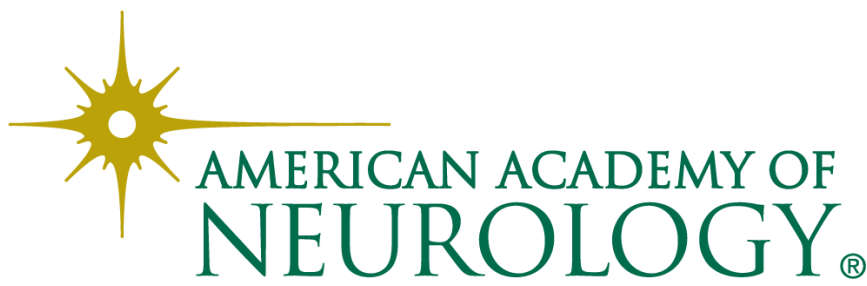

